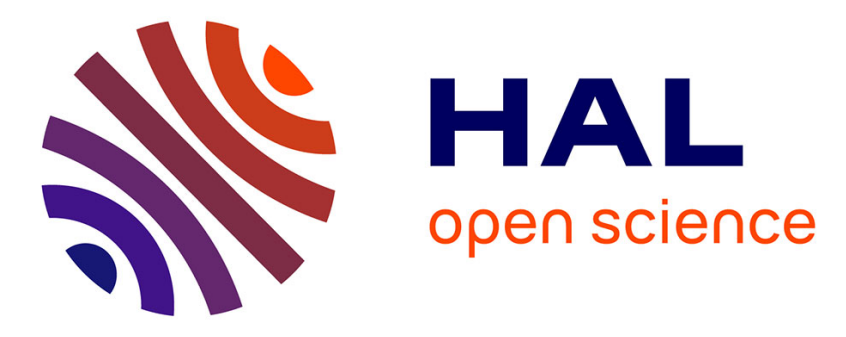

\title{
Parameterization of wind turbine impacts on hydrodynamics and sediment transport
}

Aurélie Rivier, Anne-Claire Bennis, Grégory Pinon, Vanessa Magar, Markus Gross

\section{- To cite this version:}

Aurélie Rivier, Anne-Claire Bennis, Grégory Pinon, Vanessa Magar, Markus Gross. Parameterization of wind turbine impacts on hydrodynamics and sediment transport. Ocean Dynamics, 2016, 50, pp.605 - 1299. 10.1007/s10236-016-0983-6 . hal-01537624

\section{HAL Id: hal-01537624 \\ https://hal.science/hal-01537624}

Submitted on 12 Jun 2017

HAL is a multi-disciplinary open access archive for the deposit and dissemination of scientific research documents, whether they are published or not. The documents may come from teaching and research institutions in France or abroad, or from public or private research centers.
L'archive ouverte pluridisciplinaire $\mathbf{H A L}$, est destinée au dépôt et à la diffusion de documents scientifiques de niveau recherche, publiés ou non, émanant des établissements d'enseignement et de recherche français ou étrangers, des laboratoires publics ou privés. 


\title{
Parameterization of wind turbine impacts on hydrodynamics and sediment transport
}

\author{
Aurélie Rivier $^{1,2}$ (D) Anne-Claire Bennis ${ }^{1}$ - Grégory Pinon ${ }^{2}$ - Vanesa Magar $^{3}$. \\ Markus Gross ${ }^{3}$
}

Received: 28 February 2016 / Accepted: 16 August 2016 / Published online: 14 September 2016

(C) Springer-Verlag Berlin Heidelberg 2016

\begin{abstract}
Monopile foundations of offshore wind turbines modify the hydrodynamics and sediment transport at local and regional scales. The aim of this work is to assess these modifications and to parameterize them in a regional model. In the present study, this is achieved through a regional circulation model, coupled with a sediment transport module, using two approaches. One approach is to explicitly model the monopiles in the mesh as dry cells, and the other is to parameterize them by adding a drag force term to the momentum and turbulence equations. Idealised cases are run using hydrodynamical conditions and sediment grain sizes typical from the area located off Courseulles-sur-Mer (Normandy, France), where an offshore windfarm is under planning, to assess the capacity of the model to reproduce the effect of the monopile on the environment. Then, the model is applied to a real configuration on an area including the future offshore windfarm of Courseulles-sur-Mer. Four monopiles are represented in the model using both approaches, and modifications of the hydrodynamics and sediment transport are assessed over a tidal cycle. In relation
\end{abstract}

Responsible Editor: Bruno Castelle

Aurélie Rivier

aurelie.rivier@gmail.com

1 Normandie Université, UNICAEN, UNIROUEN, CNRS, M2C, 14000 Caen, France

2 Normandie Université, UNIHAVRE, CNRS, LOMC, 76600 Le Havre, France

3 Departamento de Oceanografía Física, CICESE, Ensenada BC 22860, México to local hydrodynamic effects, it is observed that currents increase at the side of the monopile and decrease in front of and downstream of the monopile. In relation to sediment transport effect, the results show that resuspension and erosion occur around the monopile in locations where the current speed increases due to the monopile presence, and sediments deposit downstream where the bed shear stress is lower. During the tidal cycle, wakes downstream of the monopile reach the following monopile and modify the velocity magnitude and suspended sediment concentration patterns around the second monopile.

Keywords Marine renewable energy · Offshore wind farms · Numerical modelling · Hydrodynamics .

Sediment transport · Foundation

\section{Introduction}

Renewable energies have to cover $20 \%$ of European global electricity consumption by 2020 . The marine renewable energies sector contributes to this objective with resources such as waves, currents, tides and offshore wind. Offshore wind is the most mature of the offshore renewable energy technologies. However, there are still significant questions to answer regarding, for example, the impact offshore wind technologies have on the environment, in particular at array scales. The first offshore wind farm was built in Danish waters back in 1991. By June 2015, 82 wind farms were operational in European waters, with a total installed capacity of $10 \mathrm{GW}$ distributed in the North Sea, the Baltic Sea and the Atlantic Ocean (EWEA 2015). In the English Channel, five wind farms are planned to be built by 2018 on both sides (English and French), with an expected capacity of $2.8 \mathrm{GW}$ and a sixth wind farm is planned by 2021 . 
In France, an area located $10 \mathrm{~km}$ off Courseulles-sur-Mer (Calvados, Normandy, France) was selected to build one of the first French wind farms. At this location, the water depth is between 20 and $30 \mathrm{~m}$ and the bed is composed of sand and gravel. Tidal currents are strong, reaching speeds of $1 \mathrm{~m} / \mathrm{s}$ during medium spring tides and $1.3 \mathrm{~m} / \mathrm{s}$ during equinox tides. The influence of waves is weaker, as the area is protected from the Atlantic Ocean by the Cotentin Peninsula. Seventy-five turbines will be installed using monopile foundations with a diameter of $6 \mathrm{~m}$.

Offshore monopile foundations modify the hydrodynamics and sediment transport at local and regional scales. Their impact on sediment transport has been observed in the North Sea by Rees et al. (2006), Cooper et al. (2008), Vanhellemont and Ruddick (2014) and Baeye and Fettweis (2015), for instance. Computational fluid dynamics models (CFD) are able to represent the complex fluid-structure interactions around a monopile (e.g. Roulund et al. 2005, Kirkil et al. 2008). However, in general, such techniques are too computationally expensive at regional scales. A possible alternative is to use analytical expressions of drag (e.g. Edelvang et al. 1999) to evaluate the monopile effects on the hydrodynamics, but this method is simplistic. Another option is to analyse the two-dimensional case (e.g. Leballeur et al. 2013); however, a three-dimensional analysis is needed to resolved the vertical velocity profile and, in particular, the near-bed velocity, which is essential for sediment transport and bed evolution computations around monopile foundations (Christie et al. 2012).

In relation to the numerical representation of monopile foundations, a number of different approaches have been adopted. For example, some researchers have parameterized the monopile as an increase in apparent roughness at the monopile location (Lambkin et al. 2009), while others have parameterized it as a drag force term in the momentum equations (Navitus Bay Development Limited Ltd 2014). This technique has been used by a number of authors (e.g. Neill et al. 2009; Defne et al. 2011; Venayagamoorthy et al. 2011; Ahmadian and Falconer 2012; Plew and Stevens 2013; Ramos et al. 2013; Yang et al. 2013; Sánchez et al. 2014; Fallon et al. 2014; Nash et al. 2014; Robins et al. 2014; Thiébot et al. 2015) to model the impact of bridge piers, tidal turbines or fish farm pens on flow. Besides addition of drag source terms in momentum equations, Rennau et al. (2012) also implemented source terms in turbulent equations to model the effect of wind turbine foundations on mixing. This approach is used frequently to assess the impact of vegetation on flow (Temmerman et al. 2005; Bouma et al. 2007; Baptist et al. 2007) and to assess the impact of energy extraction by tidal turbines on the flow (Roc et al. 2013). In the regional model MARS3D, Kervella
(2010) parameterized the effect of oyster farming structures on hydrodynamics and sediment dynamics by increasing bed roughness. Ganthy (2011) assessed the impact of seagrass meadows composed by small and flexible Zostera noltii on the hydrodynamics and the sediment dynamics of the Arcachon Lagoon using subgrid parameterizations implemented in the momentum and turbulence equations of MARS3D's hydrodynamic module. It is worth noting that the impact of offshore wind farms on sediment transport is often assessed using the model outputs from a hydrodynamical model to estimate the bed shear stress exceedance on the empirical equations describing mobility of sediment (Lambkin et al. 2009; Navitus Bay Development Limited Ltd 2014); however, this method does not allow for a good representation of advection of the resuspended sediment and its deposition downstream of the monopile.

The objectives of this study are (i) to estimate the monopile impacts on the hydrodynamics and sediment transport using a three-dimensional regional model, MARS3D, and (ii) to find a parameterization which is able to reproduce these modifications. MARS3D solves circulation (Lazure and Dumas 2008) and sediment transport (Le Hir et al. 2011) equations and allows reasonable calculation time at a regional scale. This study does not cover the large variety of impacts that a wind turbine farm can produce, such as interaction with waves (e.g. Linton and Evans 1990; de Leon et al. 2011; García-Hermosa et al. 2014) or the windspeed deficit downstream of a wind turbine (e.g. Frandsen et al. 2006), which, in turn, modifies ocean surface currents (Ludewig 2015). The study focuses on the area of the future wind farm of Courseulles-sur-Mer (Calvados, France). Monopiles are modelled using two approaches. In the first one, monopiles are explicitly incorporated in the mesh and are represented as dry points. In the second one, a subgrid parameterization is used by adding source terms in the momentum and turbulence equations.

The paper is organized as follows: Section 2 describes the model and the methods used to represent monopiles. These methods are first tested on idealised cases having various characteristics close to Courseulles-sur-Mer site (Sections 3.1 and 3.2) in order to assess the sensibility of the model on current directions, pile diameter and grain size diameter. Then they are applied to the real case using nested ranks (Sections 4.1 and 4.2). Results are finally discussed (Sections 5).

\section{Model description}

The MARS3D model used in this study was developed by Lazure and Dumas (2008). It solves the momentum 
equations under the Boussinesq and the hydrostatic approximation and is expressed in a Cartesian coordinate system as:

$$
\frac{\partial u}{\partial t}+u \frac{\partial u}{\partial x}+v \frac{\partial u}{\partial y}+w \frac{\partial u}{\partial z}-f v=-\frac{1}{\rho_{0}} \frac{\partial p}{\partial x}+\frac{1}{\rho_{0}}\left(\frac{\partial \tau_{x x}}{\partial x}+\frac{\partial \tau_{x y}}{\partial y}+\frac{\partial \tau_{x z}}{\partial z}\right)
$$

$\frac{\partial v}{\partial t}+u \frac{\partial v}{\partial x}+v \frac{\partial v}{\partial y}+w \frac{\partial v}{\partial z}+f u=-\frac{1}{\rho_{0}} \frac{\partial p}{\partial y}+\frac{1}{\rho_{0}}\left(\frac{\partial \tau_{y x}}{\partial x}+\frac{\partial \tau_{y y}}{\partial y}+\frac{\partial \tau_{y z}}{\partial z}\right)$

where $(u, v, w)$ are the three components of velocity, $f$ is the Coriolis parameter, $\rho_{0}$ is the reference density, $p$ is the pressure and $\tau$ is the Reynolds stress tensor. The vertical component is calculated by integration of the continuity equation (Lazure and Dumas 2008), and pressure is calculated from the sea surface elevation.

An alternative direction implicit (ADI) scheme is used to solve the barotropic mode (Peaceman and Rachford Jr 1955; Leendertse 1970), which allows for larger time steps than other methods. In the horizontal, the variables are located on the grid following an Arakawa-C grid staggering. The vertical coordinate is a sigma level coordinate. Nested-grids method is available to impose more precise forcing along open boundaries. Vertical mixing is solved with the generic length scale formulation (Umlauf and Burchard 2003) using coefficients for k- $\epsilon$ model described in Warner et al. (2005). Horizontal viscosity depends on grid spacing, and it is expressed following (Okubo 1971) as:

$v_{H}=f_{v i s c} \cdot 0.01 \cdot \Delta y^{1.15}$

with $f_{v i s c}$ a coefficient ranging between 1 and 17 (taken between 1.5 and 10 in this study) and $\Delta y$ being the size of the cell in the $y$-direction.

The sediment transport module used in MARS3D is described in Le Hir et al. (2011). It solves the following advection-diffusion equation in the water column:

$$
\begin{aligned}
\frac{\partial C}{\partial t}+\nabla(\mathbf{u} C)= & \frac{\partial}{\partial x}\left(D_{H} \frac{\partial C}{\partial x}\right)+\frac{\partial}{\partial y}\left(D_{H} \frac{\partial C}{\partial y}\right) \\
& +\frac{\partial}{\partial z}\left(D_{V} \frac{\partial C}{\partial z}\right)+\frac{\partial w_{s} C}{\partial z}
\end{aligned}
$$

where $C$ is the sediment concentration, $x$ and $y$ are horizontal directions, $z$ is the vertical direction, $w_{s}$ is the settling velocity and $D_{H}$ and $D_{V}$ are the horizontal and vertical diffusion coefficients.
Erosion and deposition fluxes (E and D, respectively) are calculated using the following formulations (Le Hir et al. 2011):

$$
\begin{aligned}
E & =E_{0}\left(1-\frac{\tau}{\tau_{c e}}\right)^{n} & & \text { if } \tau>\tau_{c e} \\
& =0 & & \text { if } \tau<\tau_{c e}
\end{aligned}
$$

where $E_{0}$ is a constant of erodibility $\left(\mathrm{kg} \mathrm{m}^{-2} \mathrm{~s}^{-1}\right), \tau$ is the bed shear stress, $\tau_{c e}$ is the critical shear stress for erosion and $n=1.5$,

and

$D=w_{s} C^{b}$

where $C^{b}$ is the concentration extrapolated close to the bottom using a Rouse profile (Le Hir et al. 2011).

The critical shear stress for erosion $\tau_{c e}$ and the settling velocity $w_{s}$ are calculated following Soulsby and Whitehouse (1997) and Soulsby (1997), respectively. The choice of the formula to estimate the transport rate $E_{0}$ could modify the estimation of sediment fluxes (e.g. Camenen and Larroudé 2003), each formula being established in specific conditions. The formula used in this study is based on flume experiments with median sand grain diameter, $d$, in the 140 $450 \mu \mathrm{m}$ range in current-only conditions (Le Hir et al. 2008) and is expressed as:

$E_{0}=\min (0.27,1000 d-0.01)$.

In this study, only suspended sediment transport is considered. The quantity of sediments available in the bed varies during the simulation inducing a change of bed thickness in the sediment transport module. However, the bathymetry remains fixed in the hydrodynamical module.

The drag force exerted on the flow by the monopile is incorporated here using the method of Ganthy (2011) but with some adaptations, because in Ganthy (2011) vegetation does not fully fill the cells and a coefficient which represents the ratio of the space filled by vegetation by cell area is used. In this study, the monopile fills the cells entirely, and this coefficient is not taken into consideration.

The drag force per unit area, $\mathbf{F}_{\mathbf{d}}\left(F x_{d}, F y_{d}\right)$, induced by the monopile, is expressed in the horizontal directions ( $\mathrm{x}$ and y) as:

$$
\begin{aligned}
& F x_{d}=-\frac{1}{2} \frac{\rho_{0} C_{d} D}{\Delta x \Delta y}\left\|\mathbf{u}_{\infty}\right\| u_{\infty} \\
& F y_{d}=-\frac{1}{2} \frac{\rho_{0} C_{d} D}{\Delta x \Delta y}\left\|\mathbf{u}_{\infty}\right\| v_{\infty}
\end{aligned}
$$

where $C_{d}$ is the drag coefficient, $D$ is the diameter of the pile, $\mathbf{u}_{\infty}\left(u_{\infty}, v_{\infty}\right)$ is the undisturbed current velocity upstream of the pile, $\Delta x$ and $\Delta y$ are the horizontal grid sizes and $\|$.$\| is the \mathbb{L}^{2}$ norm. These terms, divided by the water 
density $\rho_{0}$, are added to the right hand side of equations (1) and (2), respectively.

Dependence of $C_{d}$ on several parameters is determined by modelling benchmark test cases. Results of simulations indicate that the drag coefficient $C_{d}$ depends on the depth $(z)$, on the horizontal viscosity $\left(v_{H}\right)$ and the angle $(\theta)$ between the input current and the longitudinal axis. The drag coefficient is doubled at the bottom cell. This increase of the drag coefficient close to the bed can be justified by the velocity dependence on the drag coefficient (increasing strongly for lower velocities-cf Achenbach 1968) and a different shape of the obstacle (junction of the bed and the cylinder). Using a higher $C_{d}$ value close to the bottom could also be interpreted as a way to account for the presence of the horseshoe vortex, that cannot be explicitly computed with the used discretisation in the regional model. Additionally, horseshoe vortices usually have the size of a diameter (Roulund et al. 2005), which is coherent with the doubling of the $C_{d}$ value for a given pile diameter. Because of the grid type (Arakawa-C), with rectangular cells, and the spatial resolution, the monopiles modelled with both approaches have sharp edges. The monopile shape influences the drag coefficient (e.g. Lindsey 1938). For weak mixing (for instance $v_{H}=0.10 \mathrm{~m}^{2} \mathrm{~s}^{-1}$ ), $C_{d}$ has to vary with the angle $\theta$. For a strong horizontal viscosity (i.e. above $0.2 \mathrm{~m}^{2} \mathrm{~s}^{-1}$ ), mixing smooths the effect of these sharp edges and $C_{d}$ does not depend on $\theta$.

With these modifications, the turbulence equations for vertical viscosity become:

$\frac{\partial k}{\partial t}=\frac{\partial}{\partial z}\left(\frac{\nu_{V}}{s_{k}} \frac{\partial k}{\partial z}\right)+P-\epsilon+\frac{\left\|\mathbf{F}_{\mathbf{d}}(\mathbf{z})\right\|}{\rho_{0}}\left\|\mathbf{u}_{\infty}\right\|$

$\frac{\partial \epsilon}{\partial t}=\frac{\partial}{\partial z}\left(\frac{\nu_{V}}{s_{\epsilon}} \frac{\partial \epsilon}{\partial z}\right)+\frac{\epsilon}{k}\left(C_{1} P-C_{2} \epsilon F_{\text {wall }}+C_{2} \frac{\left\|\mathbf{F}_{\mathbf{d}}(\mathbf{z})\right\|}{\rho_{0}}\left\|\mathbf{u}_{\infty}\right\|\right)$

where $k$ is the turbulent kinetic energy, $\epsilon$ is the dissipation, $P$ represents the effects of shear production and $C_{1}, C_{2}, s_{k}$, $s_{\psi}$ are empirical constants. Buoyancy is neglected in turbulence equations. For a $k-\epsilon$ turbulence model, their default values are $C_{1}=1.44, C_{2}=1.92, s_{k}=1, s_{\psi}=1.3$ and $F_{\text {wall }}=1$ (Umlauf and Burchard 2003).

The distance between the pile and the location $\left(i_{\infty}, j_{\infty}\right)$ where the velocity is considered undisturbed $\left(\mathbf{u}_{\infty}\right)$ was determined using the dry point approach for a pile with a diameter of $6 \mathrm{~m}$ and input velocities ranging between 0.3 and $1.2 \mathrm{~m} / \mathrm{s}$. Velocities are considered undisturbed when they differ from the velocity at the entrance of the domain by $1 \%$ or less. Based on these tests, the velocity $\mathbf{u}_{\infty}$ is set $90 \mathrm{~m}$ upstream of the pile. In the following simulations, the location $\left(i_{\infty}, j_{\infty}\right)$ varies with the current direction. It is determined such as (i) the line monopile- $\left(i_{\infty}, j_{\infty}\right)$ is collinear with current vector at the entrance of the domain, and (ii) the distance between the location of the undisturbed velocity and the monopile is $90 \mathrm{~m}$.

The modifications on the hydrodynamics and sediment dynamics induced by the monopile foundations will be presented using the relative difference which is expressed for a variable $V$ as :

$\Delta V_{\text {rel }}=\frac{V_{\text {monopile }}-V_{\text {ref }}}{V_{\text {ref }}}$,

where $V_{\text {monopile }}$ and $V_{\text {ref }}$ are the values of the variable with and without monopile, respectively. The use of the dry points or parameterization approach will be indicated in each case.

\section{Idealised cases}

\subsection{Configuration}

The aim is to simulate the flow around a monopile. The results given by the parameterization are compared with those of the dry cell points method. Previously, Rivier et al. (2014) performed simulations on an idealised case which reproduced the semi-diurnal tidal cycle. In the same study, velocity downstream of a monopile simulated with the dry point approach were also compared with experimental measurements. Figure 1 shows the mesh around the monopiles for two different diameters of monopile (6 and $15 \mathrm{~m}$ ). Grey cells are considered as dry points in the first approach, and the parameterizations are applied in these grey cells in the second approach. The domain is a rectangular area $2100 \mathrm{~m}$ long, $900 \mathrm{~m}$ large and $30 \mathrm{~m}$ deep, which is a typical depth of the future windfarm at Courseulles-sur-Mer. The horizontal resolution and the time step are $3 \mathrm{~m}$ and $0.5 \mathrm{~s}$, respectively. The water column is divided into 15 sigma levels that are equally distributed. Dirichlet conditions are used for velocity and sea surface height at boundaries and the incoming velocity is set to $0.6 \mathrm{~m} \mathrm{~s}^{-1}$. The monopile is located in the middle of the domain. Four values of horizontal viscosity between $5.3 \times 10^{-2}$, and $3.5 \times 10^{-1} \mathrm{~m}^{2} \mathrm{~s}^{-1}$ are tested against laboratory data and a simulation by $\mathrm{Li}$ et al. (2014). Simulations using $v_{H}=1.0 \times 10^{-1} \mathrm{~m}^{2} \mathrm{~s}^{-1}$ $\left(f_{\text {visc }}=2.8\right.$ in Eq. 3, Fig. 2) give the best description of the hydrodynamics. The study of idealised cases is performed with this value of $v_{H}$. The capacity of the model to represent the hydro-sedimentary effects of the monopile is evaluated. Table 1 summarizes the different configurations tested with variations in the velocity directions, the diameter of the monopile, the grain size diameter and the origin of the sediment (bed or input from boundaries). In the sixth simulation, the very fine sediment (with a diameter of $65 \mu \mathrm{m}$ instead of $250 \mu \mathrm{m}$ ), is initially only in the water column 
Fig. 1 Mesh around the monopile (grey cells) with a diameter equal to $\mathbf{a} 6 \mathrm{~m}$ and $\mathbf{b}$ $15 \mathrm{~m}$
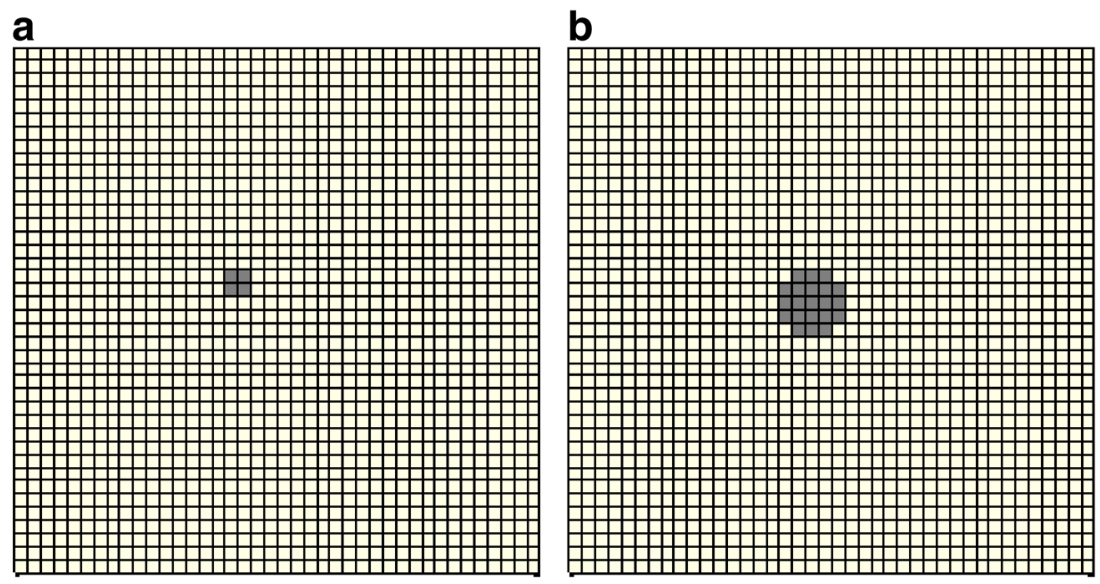

(instead of in the bed) and is applied at the boundaries with a concentration of $5 \mathrm{mg} / \mathrm{l}$.

$C_{d}$ is chosen, in agreement with measurements made by Achenbach (1968) for Reynolds numbers between $3.6 \times 10^{6}$ and $9 \times 10^{6}$, and in agreement as well with the value of $C_{d}$ for the Baltic Sea taken by Rennau et al. (2012), equal to 0.65 for $\theta=0^{\circ}$ in the water column, except for the cell closest to the bottom where it is twice that value (horizontal viscosity equal to $1.0 \times 10^{-1} \mathrm{~m}^{2} \mathrm{~s}^{-1}$ ). $C_{d}$ increases for $\theta=20^{\circ}$ and $\theta=40^{\circ}$ because of the sharp edges of the grid. More details about increase of $C_{d}$ are given in Section 2. The roughness length $z_{0}$ is constant over the computational domain, and is taken as $3.5 \times 10^{-4} \mathrm{~m}$ as suggested for mixed beaches of sand and gravel (Soulsby 1997).

\subsection{Numerical results}

Figures 3 and 4 show the relative difference (defined in Eq. 12) of velocity magnitude at the surface, near the bed and in the water column along the central axis, including the monopile, for $\theta=0^{\circ}$ (case 1 of Table 1). The parameterization method (right) reproduces well the patterns obtained with the explicit method (left). With both approaches, the current velocity decreases in front of the monopile and increases on the side (as expected). A wake

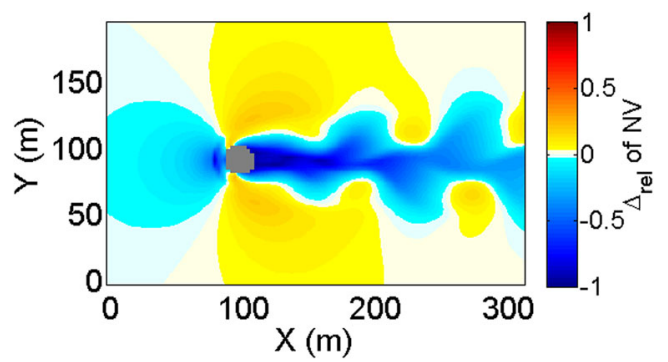

Fig. 2 Relative difference ( $\Delta_{r e l}$ defined in Eq. 12) of magnitude of current velocity near-bed $(N V)$ with horizontal viscosity equal to $1.0 \times 10^{-1} \mathrm{~m}^{2} \mathrm{~s}^{-1}$. Dry cells are shown in grey forms downstream of the monopile, where the velocity strongly decreases. The pattern and the intensity of the relative difference of velocity induced by the monopile is not the same close to the bed (Fig 3c, d) and at the surface (Fig. 3a, b). The area on the side (front) of the monopile where the current speed increases (decreases) is larger near the bed than at the surface.

The transversal cross-section plots (Fig. 4) confirm this difference of monopile effect on velocity depending on the vertical position in the water column. The parameterization reproduces well the vertical profile of relative difference of current velocity modelled with the dry point approach, especially in front of the monopile, and downstream close to the bottom.

Figure 5 shows the relative difference of current velocity with different current directions (cases 2 and 3 of Table 2). Due to the dependency of $C_{d}$ on the flow direction, the pattern of relative difference are similar with both approaches for both angles. Patterns are still the same with different angles. The difference between the surface and the bottom is observed for the direction as well. For a larger value of horizontal viscosity (i.e. $0.2 \mathrm{~m}^{2} \mathrm{~s}^{-1}$ ), the velocity fields obtained with the parameterization method are similar to those obtained with the dry point approach without changing $C_{d}$ with $\theta$.

Figure 6 presents the relative difference of bed shear stress and bed thickness for two different monopile diameters. For both cases, bed shear stresses are in agreement with the fields of near-bed current velocity (Figs. 2 and 3c). With the diameter equal to $6 \mathrm{~m}$ (Fig. 6a, b, c, d and case 1), the presence of the monopile increases the bed shear stress at the side and decreases it in front of and downstream of the cylinder. For case 4 (Fig. 6e, f), simulations are run with a higher Reynolds number $\left(\operatorname{Re}=9.0 \times 10^{6}\right)$ and a larger monopile $(D=15 \mathrm{~m})$ which is included in 21 cells instead of 4 for the first test case. Vortices appear downstream of the monopile, leading to a periodical increase of the bed shear stress in the wake of the monopile. 
Table 1 Characteristics of idealised configurations

\begin{tabular}{|c|c|c|c|c|c|c|c|c|}
\hline Case & Pile diameter (m) & $\theta\left({ }^{\circ}\right)$ & Sediment grain size $(\mu \mathrm{m})$ & $w_{s}\left(\mathrm{~mm} \mathrm{~s}^{-1}\right)$ & $\tau_{c e}\left(\mathrm{~N} \mathrm{~m}^{-2}\right)$ & $\mathrm{E}_{0}\left(\mathrm{~kg} \mathrm{~m}^{-2} \mathrm{~s}^{-1}\right)$ & Initial location of sediment & $\mathrm{C}_{d}$ \\
\hline 1 & 6 & 0 & 250 & 30 & 0.19 & 0.24 & Bed & 0.65 \\
\hline 2 & 6 & 20 & 250 & 30 & 0.19 & 0.24 & Bed & 0.72 \\
\hline 3 & 6 & 40 & 250 & 30 & 0.19 & 0.24 & Bed & 0.79 \\
\hline 4 & 15 & 0 & 250 & 30 & 0.19 & 0.24 & Bed & $\mathrm{X}$ \\
\hline 5 & 15 & 0 & 500 & 68 & 0.26 & 0.27 & Bed & $\mathrm{X}$ \\
\hline 6 & 15 & 0 & 65 & 2.5 & 0.12 & 0.055 & Water column & $\mathrm{X}$ \\
\hline
\end{tabular}

The increase of the bed shear stress leads to erosion of the bed. For case 1, the suspended sediment concentration increases close to the bottom and the bed thickness decreases at the side. The bed is not eroded downstream of the monopile because the bed shear stress is lower than the critical bed shear stress for erosion at this location. Sediments eroded close to the monopile are deposited upstream and downstream, especially on the side of the wake. The bed is eroded with ripples for case 4 because of the oscillations downstream of the monopile (Fig. 6f).

A simulation with a larger grain size diameter, equal to $500 \mu \mathrm{m}$, was also run (case 5 of Table 1). The resulting relative difference of bed thickness is presented in Fig. 7. For this grain size, corresponding to the sediment median grain diameter at the Courseulles-sur-Mer area, the bed shear stress does not increase enough to cause sediment erosion around the monopile (with a input current equal to $0.6 \mathrm{~m} \mathrm{~s}^{-1}$ ).
For case 6, very fine sand (diameter of $65 \mu \mathrm{m}$ ) is introduced in all the water column and at the boundaries. These very fine sediments are still in suspension at the surface downstream of the monopile: a turbid wake appears (Fig. 8).

\section{Real configuration: Courseulles-sur-Mer (Calvados, France)}

\subsection{Configuration}

The regional model MARS is applied in two (2D) and three dimensions (3D) in the domain of interest on November 2011. This study focuses on one semi-diurnal tidal cycle on the 11th of November 2011. This date is chosen because the tide range is medium (tidal range equal to $5.6 \mathrm{~m}$ ) and waves are weak. Hence, waves are neglected in this study. Five nested domains (also called ranks), described in Table 2
Fig. 3 Relative difference $\left(\Delta_{r e l}\right.$ defined in Eq. 12) of magnitude of current velocity at the surface $(\mathrm{SV}, \mathbf{a}, \mathbf{b})$, nearbed $(\mathrm{NV}, \mathbf{c}, \mathbf{d})$ using the dry point method (a, c, dry cells are shown in grey) and the parameterization $(\mathbf{b}, \mathbf{d}$, black lines indicate pile location). The numerical parameters are those of case 1 presented in Table 1 a
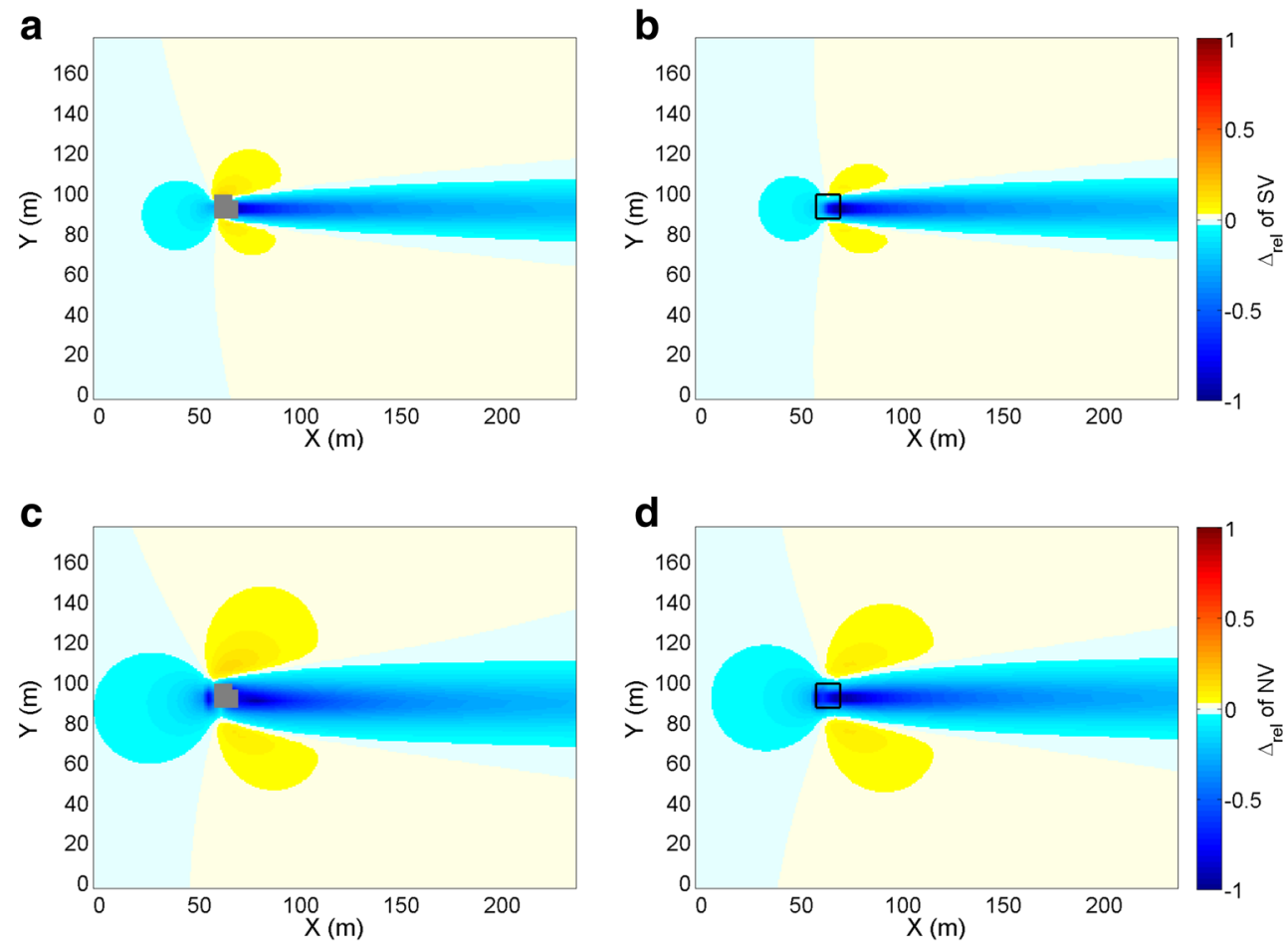

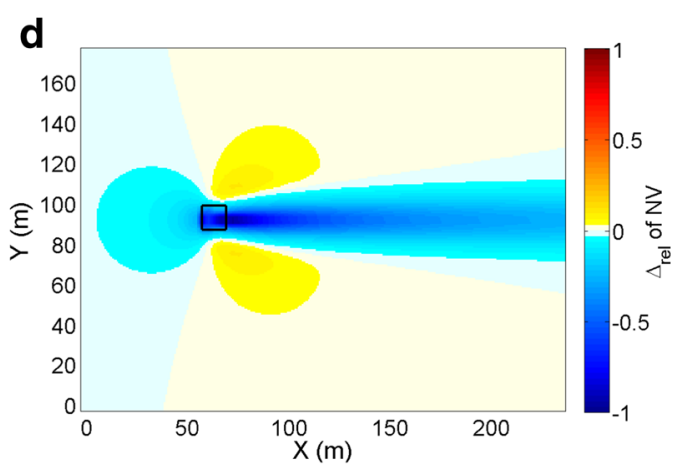


Fig. 4 Relative difference $\left(\Delta_{r e l}\right.$ defined in Eq. 12) of magnitude of current velocity $(\mathrm{V})$ inside the water column along the central axis using the dry point method (a, dry cells are shown in grey) and the parameterization (b, black lines indicate pile location). The numerical parameters are those of case 1 presented in Table 1
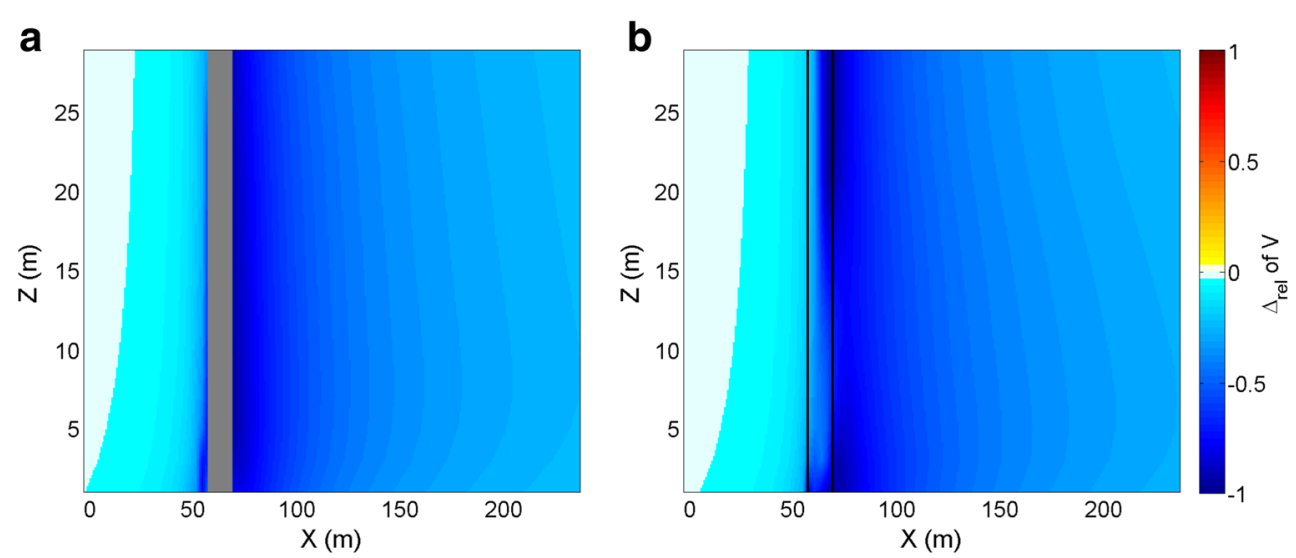

and depicted in Fig. 9, are used to allow a high resolution and to take into account explicitly the monopile in the mesh. Ranks 0, 1, 2, and 3 are solved in 2D to reduce computational time and cost. Rank 4 is initialized with the velocity fields from the previous rank and is solved in $3 \mathrm{D}$ with 15 levels in the water column. It is coupled with
Fig. 5 Relative difference $\left(\Delta_{r e l}\right.$ defined in Eq. 12) of magnitude of current velocity at the surface $(\mathrm{SV}, \mathbf{a}, \mathbf{b}, \mathbf{e}, \mathbf{f})$ and near the bed $(\mathrm{NV}, \mathbf{c}, \mathbf{d}, \mathbf{g}, \mathbf{h})$ with current direction equal to $20^{\circ}(\mathbf{a}-\mathbf{d})$ and $40^{\circ}$ (e-h) using the dry point method (a, c, e, $\mathbf{g}$, dry cells are shown in grey) and the parameterization $(\mathbf{b}, \mathbf{d}, \mathbf{f}, \mathbf{h}$, black lines indicate pile location). The numerical parameters are those of cases 2 and 3 presented in Table 1
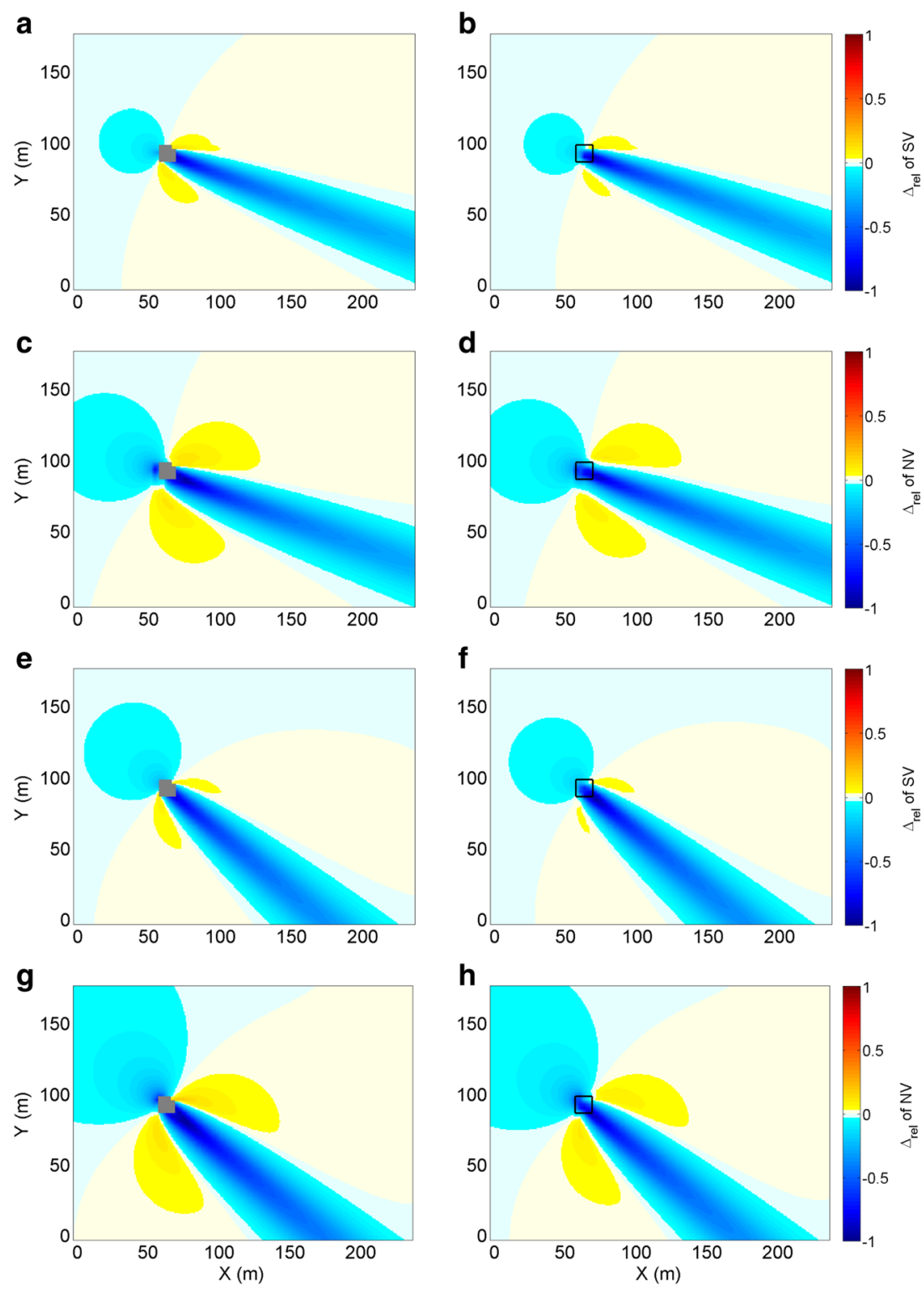
Table 2 Characteristics of Courseulles-sur-Mer configuration

\begin{tabular}{|c|c|c|c|c|c|c|}
\hline Rank & $\begin{array}{l}\text { Mesh } \\
\text { size }(\mathrm{m})\end{array}$ & $\begin{array}{l}\text { Time } \\
\text { step (s) }\end{array}$ & $\begin{array}{l}\text { Horizontal } \\
\text { mixing } \\
\left(\mathrm{m}^{2} \mathrm{~s}^{-1}\right)\end{array}$ & $2 \mathrm{D} / 3 \mathrm{D}$ & $\begin{array}{l}\text { Vertical } \\
\text { level }\end{array}$ & $\begin{array}{l}\text { Start date } \\
(2011)\end{array}$ \\
\hline 0 & 243 & 20 & 55.4 & $2 \mathrm{D}$ & $\mathrm{x}$ & 09/11 03:00 \\
\hline 1 & 81 & 10 & 15.7 & $2 \mathrm{D}$ & $\mathrm{x}$ & 09/11 08:10 \\
\hline 2 & 27 & 5 & 4.43 & $2 \mathrm{D}$ & $\mathrm{x}$ & 09/11 20:20 \\
\hline 3 & 9 & 1 & 1.25 & $2 \mathrm{D}$ & $\mathrm{x}$ & $10 / 1108: 45$ \\
\hline 4 & 3 & 0.5 & 0.35 & $3 \mathrm{D}$ & 15 & 10/11 21:00 \\
\hline
\end{tabular}

the sediment transport module which starts on the 11th of November 2011 at 09:00, when the hydrodynamics are well established.

For rank 0, data from SHOM (French Navy) force the sea surface height and zero velocity gradients are imposed along open boundaries. Data from the previous ranks are used to force velocities and sea surface elevation along open boundaries for the other ranks (Dirichlet conditions). A network of four monopiles with a diameter of $6 \mathrm{~m}$ is placed in this last domain, with a positioning similar to the configuration of the Courseulles-sur-Mer wind farm, using both approaches. The mesh around the monopile is the same as in the idealised cases (Fig. 1a). The bed thickness is set to $1 \mathrm{~m}$ with a homogeneous sediment grain size diameter of $250 \mu \mathrm{m}$, typical for sand.

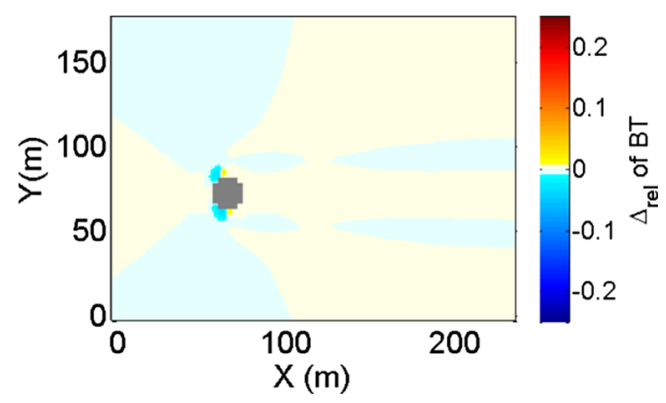

Fig. 7 Relative difference $\left(\Delta_{\text {rel }}\right.$ defined in Eq .12) of bed thickness (BT) using a sediment with a grain size diameter equal to $500 \mu \mathrm{m}$ and a pile diameter equal to $15 \mathrm{~m}$ after $6 \mathrm{~h}$. Dry cells are shown in grey. The numerical parameters are those of case 5 presented in Table 1

In a real configuration, the flow is more turbulent due to variations of bathymetry for instance. To take into account this increase of mixing, $f_{v i s c}$ is set to 10 , which leads to a horizontal viscosity of $0.35 \mathrm{~m}^{2} \mathrm{~s}^{-1}$ for rank 4 (with spatial resolution of $3 \mathrm{~m}$ ), compared to a viscosity of $0.1 \mathrm{~m}^{2} \mathrm{~s}^{-1}$ for the idealised cases. However, this increase of the horizontal viscosity reduces the effect of the drag force $\mathbf{F}_{\mathbf{d}}$ on the flow. In consequence, $C_{d}$ is increased to 1 to maintain a qualitative similarity (in terms of velocity magnitude and spatial distribution) between the two methods. For this value of horizontal viscosity, $C_{d}$ is the same for all current directions because horizontal mixing smooths the effect of
Fig. 6 Relative difference $\left(\Delta_{r e l}\right.$ defined in Eq. 12) of bed shear stress (BSS, a, c, e) and bed thickness (BT, b, d, f) with a pile diameter equal to $6 \mathrm{~m}$ using dry point method $(\mathbf{a}, \mathbf{b})$ and parametrisation $(\mathbf{c}, \mathbf{d})$, and $15 \mathrm{~m}$ using dry point method $(\mathbf{e}, \mathbf{f})$ after $6 \mathrm{~h}$. Dry cells are shown in grey and black lines indicate pile location. The numerical parameters are those of cases 1 and 4 presented in Table 1
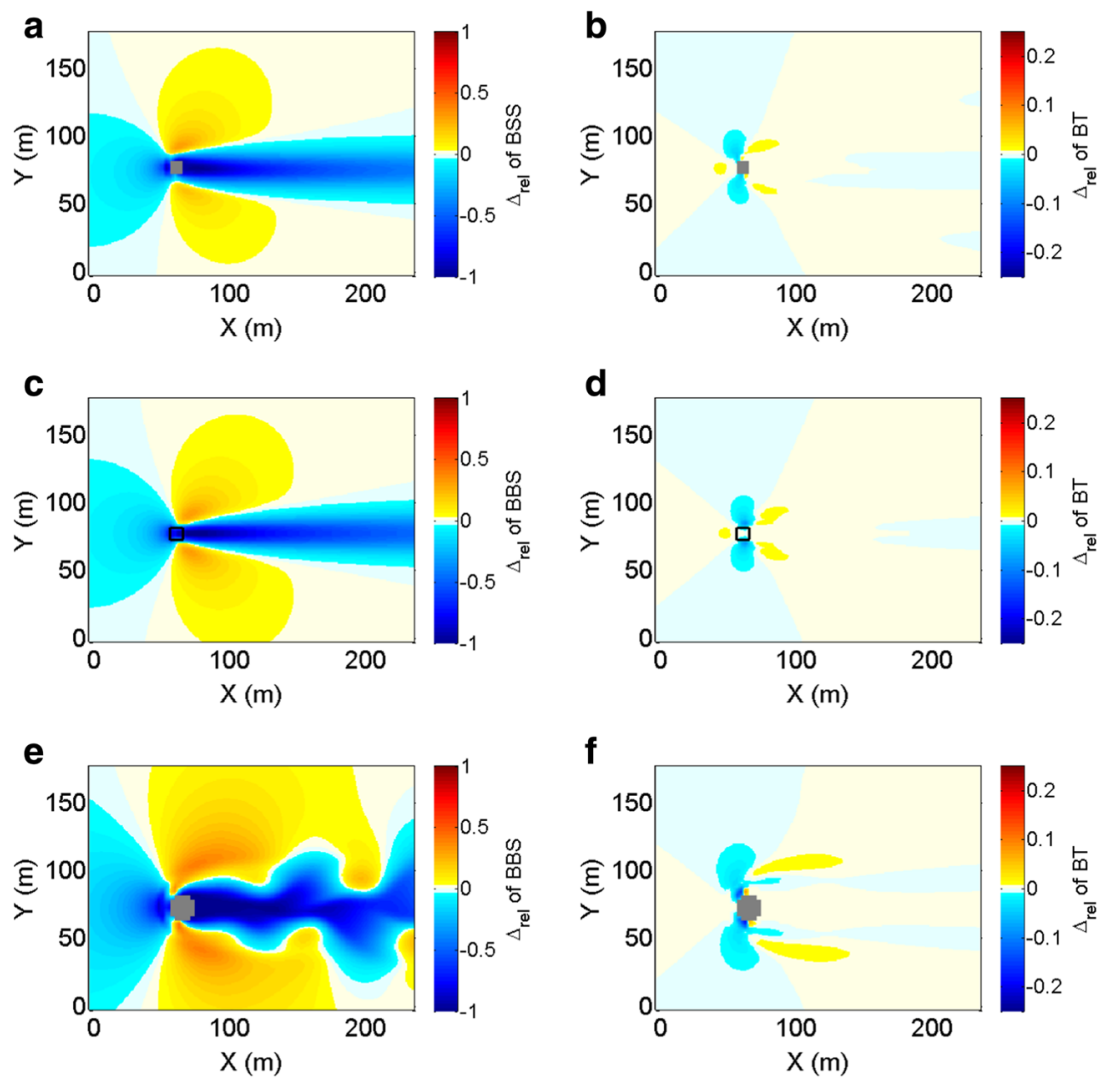


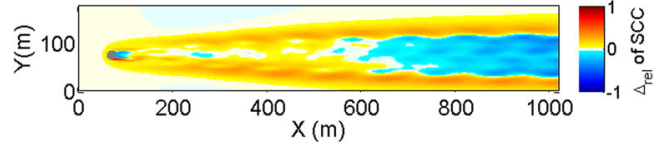

Fig. 8 Relative difference ( $\Delta_{r e l}$ defined in Eq. 12) of suspended sediment concentration (SSC) at the surface averaged over $12 \mathrm{~h}$ using a sediment with a grain size diameter equal to $65 \mu \mathrm{m}$ and a pile diameter equal to $15 \mathrm{~m}$. Dry cells are shown in grey. The numerical parameters are those of case 6 presented in Table 1

sharp edges. $C_{d}$ is still twice higher in the cell closest to the bottom (see Section 2).

\subsection{Numerical results}

Figures 11, 12 and 13 show the relative difference of nearbed velocity due to a network of four monopiles located off Calvados during a semi-diurnal tidal cycle at three different instants, described in Fig. 10: during ebb tide (T1, Fig. 11), at slack water (T2, Fig. 12) and during flood tide (T3, Fig. 13). At each time step, a wake downstream of each monopile is formed and its length and shape differ. The dry points approach and parameterization lead to similar results.

During ebb tide (time T1, Fig. 11), wakes are longer than the distance between monopiles, so longer than $950 \mathrm{~m}$. The decrease of velocity is above $10 \%$ up to approximately $500 \mathrm{~m}$ downstream and above $5 \% 1500 \mathrm{~m}$ downstream. The flow has not reached the undisturbed velocity flow up to $2 \mathrm{~km}$ downstream of the monopiles.

At slack waters (time T2, Fig. 12), the current direction changes and the velocity magnitude is small $\left(<0.15 \mathrm{~m} \mathrm{~s}^{-1}\right)$. Wakes are small $(<100 \mathrm{~m})$ and do not reach the monopile from the other rows. An area where the velocity increases is seen between the monopile located at the western part of the domain. However, this velocity increase is not significant $\left(<5 \%\right.$ of $\left.0.15 \mathrm{~m} \mathrm{~s}^{-1}\right)$.

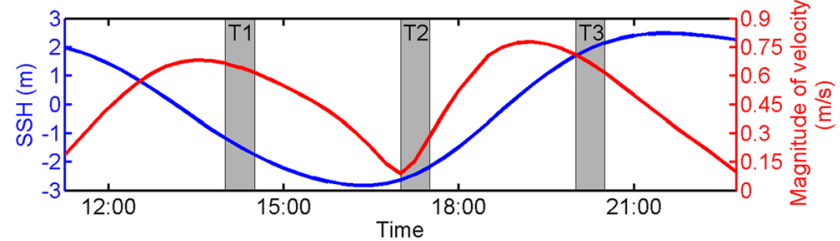

Fig. 10 Mean sea surface height (SSH) and magnitude of current during the simulation

Figures 13 and 15 show the relative difference of nearbed velocity during flood tide one hour after the velocity magnitude reached its maximum (time T3). The wakes and the rows of wind turbines are aligned. The wake caused by an upstream monopile reaches the downstream monopile, located $950 \mathrm{~m}$ downstream.

Figure 14 shows time-series of the barotropic velocity's magnitude at three locations between the two monopiles located at the bottom of the domain. These three locations, shown on Fig. 13, are P1, $23 \mathrm{~m}$ behind; P2, $66 \mathrm{~m}$ behind; and P3, $283 \mathrm{~m}$ behind the first monopile. During ebb tide (until 17:00), the velocity magnitude is not modified by the monopile's presence except at point P1. This point is included in the area where the velocity decreases in front of the monopile, when the current direction is north-west. During flood tide, the velocity's magnitude strongly decreases, especially in the two first points P1 and P2. Differences between results with the dry cells and the parameterization methods are observed at $\mathrm{P} 1$, but at $\mathrm{P} 2$ and $\mathrm{P} 3$ similar results are observed with the two approaches. The velocity's magnitude decreases at point P3 between 20:00 and 21:00 when the flow wake reaches this point.

The patterns simulated around the first monopile (Fig. 15, top, located at the bottom left-hand side in Fig. 11) are in agreement with the patterns found in the idealised cases (Figs. 3 and 5) with both approaches. However, results
Fig. 9 Computational domain. Rank 0 are represented with a red grid, rank 1 with a green grid, rank 2 with a pink grid, rank 3 with a blue grid and rank 4 with a brown grid. Black line is the coastline and grey area the land

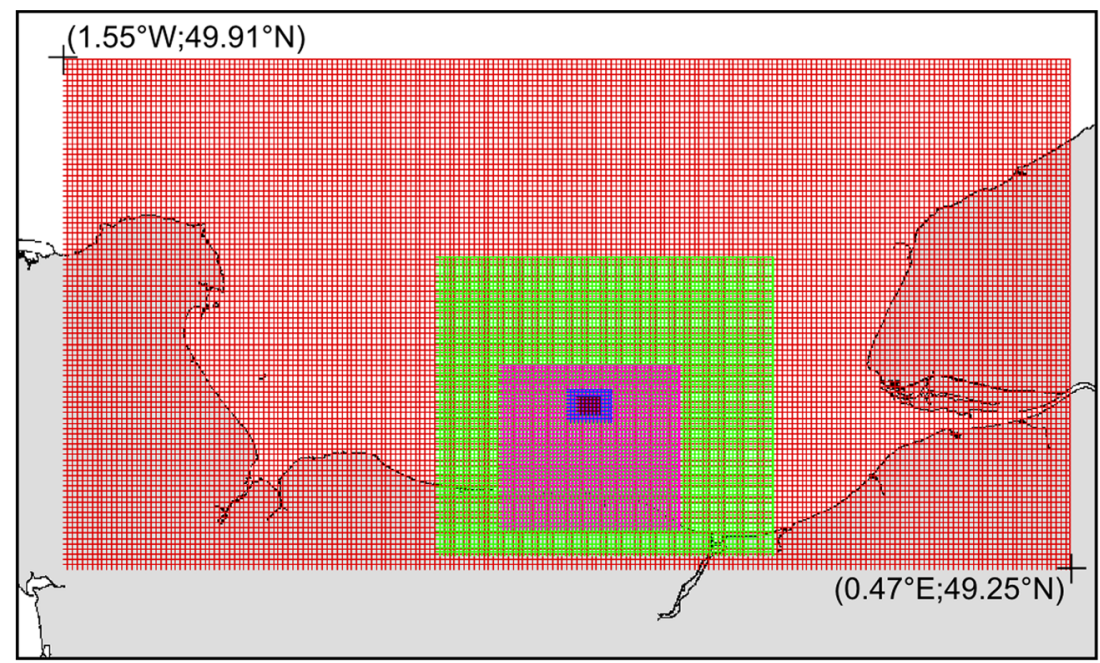



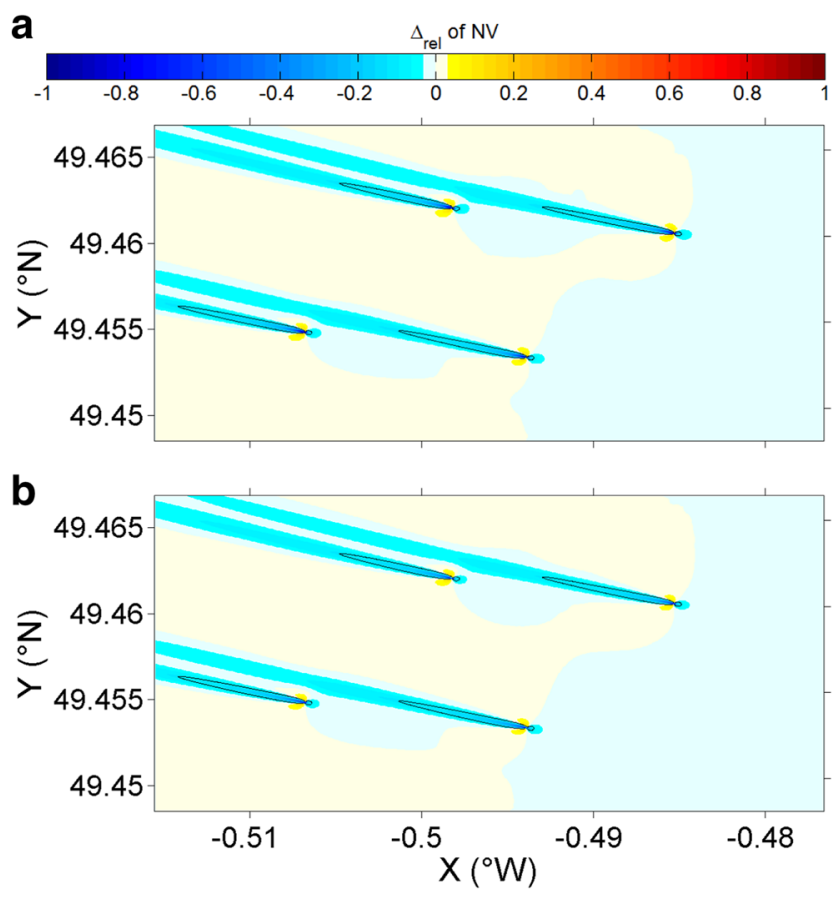

Fig. 11 Relative difference ( $\Delta_{r e l}$ defined in Eq. 12) of velocity nearbed $(N V)$ using explicit approach (top, dry cells are shown in grey) and parameterization approach (bottom) the 11 November 2011 in domain 4 at $\mathrm{T} 1=14: 30$. Black lines indicate the contour for $\Delta_{\text {rel }}=-0.2$. The numerical parameters are those of rank 4 presented in Table 2
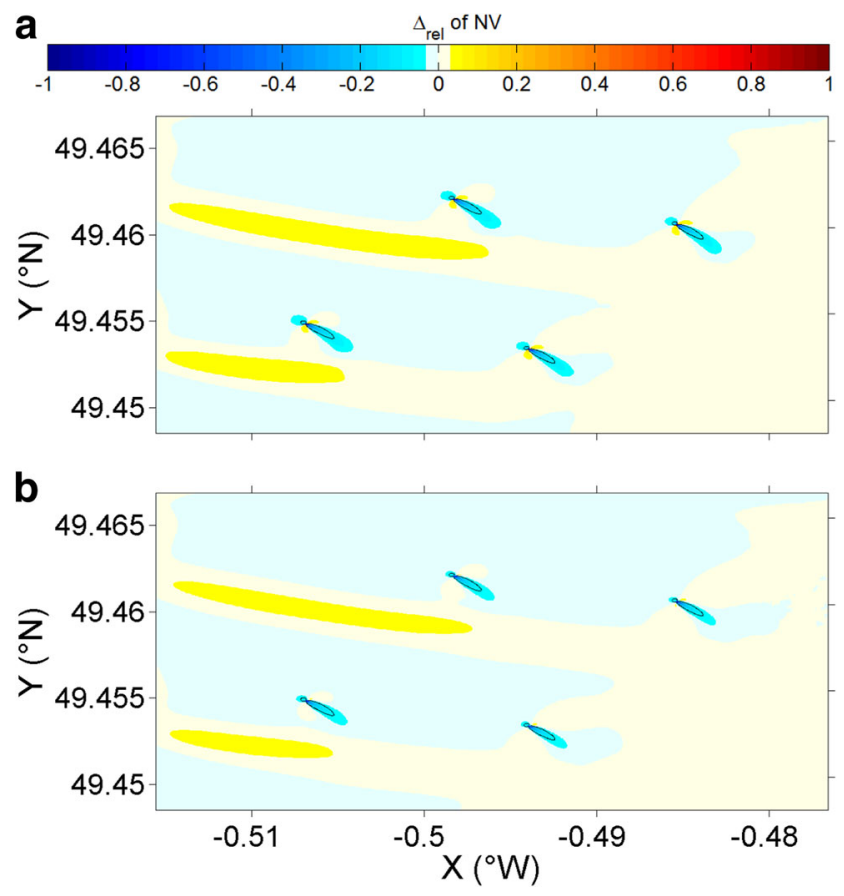

Fig. 12 Relative difference ( $\Delta_{r e l}$ defined in Eq. 12) of velocity nearbed $(N V)$ using explicit approach (top, dry cells are shown in grey) and parameterization approach (bottom) the 11 November 2011 in domain 4 at T2 $=17: 30$. Black lines indicate the contour for $\Delta_{r e l}=-0.2$. The numerical parameters are those of rank 4 presented in Table 2
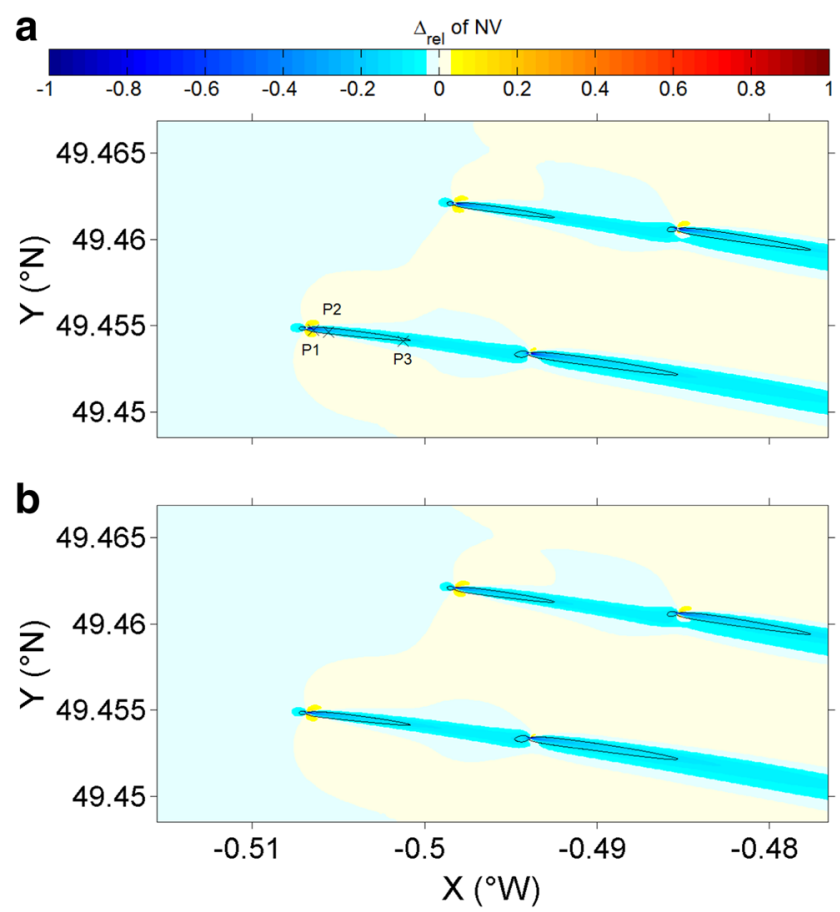

Fig. 13 Relative difference $\left(\Delta_{\text {rel }}\right.$ defined in Eq. 12$)$ of velocity nearbed $(N V)$ using explicit approach (top, dry cells are shown in grey) and parameterization approach (bottom) the 11 November 2011 in domain 4 at T3 $=20: 30$. Black lines indicate the contour for $\Delta_{\text {rel }}=-0.2$. The numerical parameters are those of rank 4 presented in Table 2

differ around the monopile located downstream (second monopile, located at the bottom right-hand side in Fig. 11). The increase of velocity at the side and the decrease in front of the monopile are lower around the second monopile than around the first monopile. These changes of velocity fields lead to modifications of the bed shear stress. Hence, the quantity of sand eroded and the concentration of suspended sediment (Fig. 16) are modified. Modifications are stronger for the relative difference of suspended sediment concentrations in comparison to the relative difference of near-bed velocity, because the erosion flux is a function of the square of the nearbed velocity. However, the wake behind the monopile is similar for both monopiles.

Figure 17 shows the relative difference of bed thickness after $12 \mathrm{~h}$ after the start of the sediment transport module around a monopile (monopile located at the bottom lefthand side in Fig. 11). Results with both approaches are similar. The bed is eroded at the side edge of the monopile in the same manner as for test cases with a fixed current. Because of the tidal cycle, sediments deposit alternately at the left and at the right side of the monopile. The pattern of deposition is not exactly symmetric. Erosion and deposition are higher close to the monopile with the parameterization in comparison with the dry points method. 
Fig. 14 Time series of barotropic velocity's magnitude at points $\mathrm{P} 1, \mathrm{P} 2$ and $\mathrm{P} 3$ without monopile (black, $W P$ ), and with monopiles using explicit approach (green, PILE) and parameterization approach (red, $P A R)$. $\mathrm{P} 1, \mathrm{P} 2$ and $\mathrm{P} 3$ are located in Fig. 13

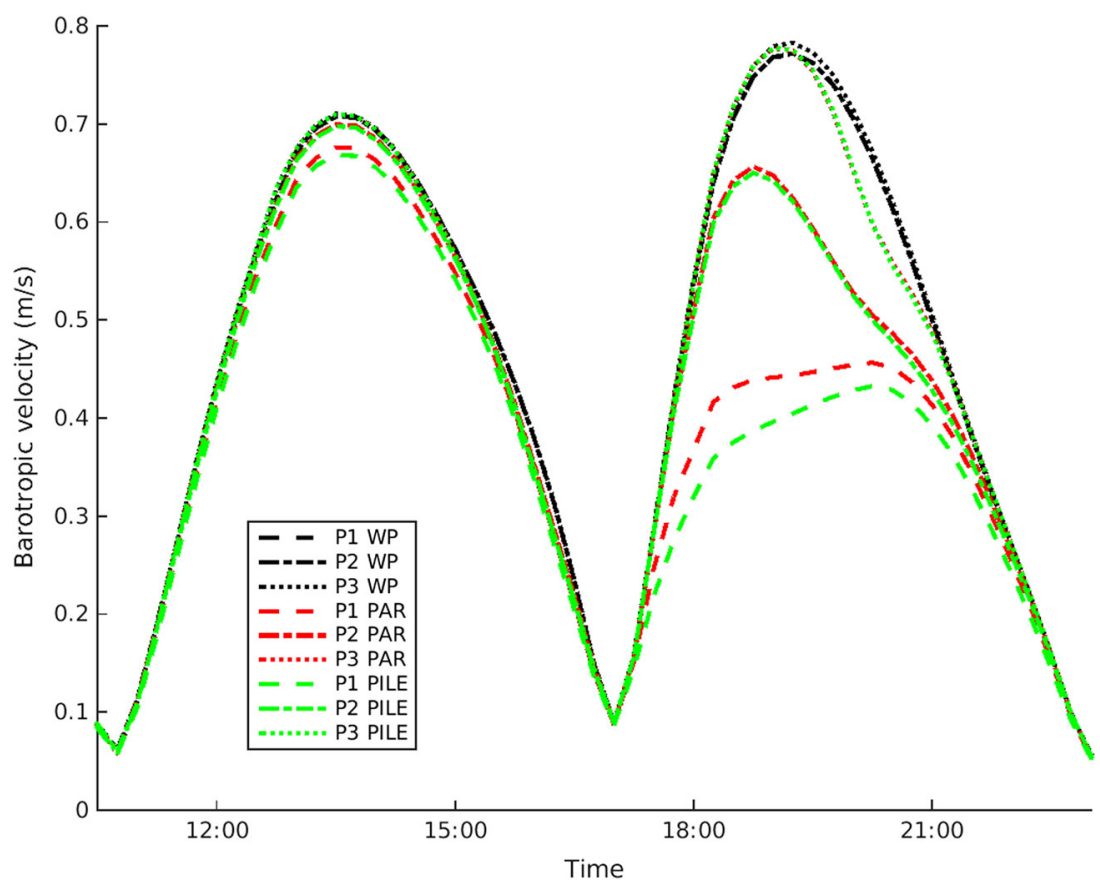

\section{Discussion}

Simulations of idealised configurations clearly show that velocity fields are differently modified by the monopile near the bed and at the sea-surface. The vertical structure of our simulated velocity fields are in agreement with measurements by Graf and Yulistiyanto (1998) and Dargahi (1989), who also observed differences in the wake width near the flume bed and at the surface. Hence, these 3D aspects are not artefacts of numerical modelling and have to be considered. Physically speaking, the flow is differently modified by the monopile close to the seabed due to the appearance

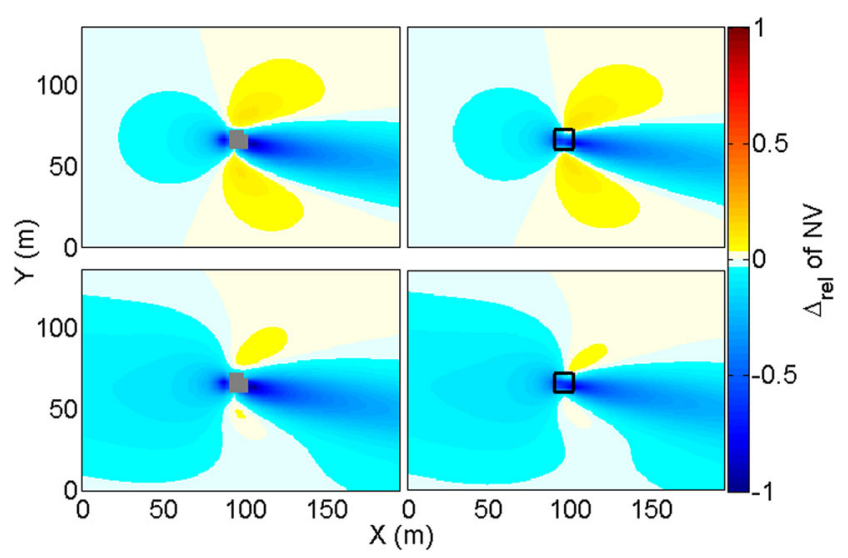

Fig. 15 Relative difference ( $\Delta_{\text {rel }}$ defined in Eq. 12) of velocity nearbed $(N V)$ around the monopiles located at the bottom left-hand side (top) and at the bottom right-hand side (bottom) in Fig. 13 using explicit approach (left, dry cells are shown in grey) and parameterization approach (right, black lines indicate pile location) at 20:30. The numerical parameters are those of rank 4 presented in Table 2 of the horseshoe vortex (Sumer and Fredsøe 1997; Roulund et al. 2005). This horseshoe vortex appears in front of and at the side of the monopile because of flow interactions with the seabed and the monopile. However, our horizontal resolution of $3 \mathrm{~m}$ is not able to fully reproduce horseshoe vortices, especially in the cases with a pile diameter of $6 \mathrm{~m}$. This is due to the fact that the diameter of the horseshoe vortex is less than the pile diameter (Roulund et al. 2005), so less than the size of two cells. In the case where the pile diameter is larger $(15 \mathrm{~m})$, a more complex flow structure is reproduced by the model. This is due to a higher Reynolds

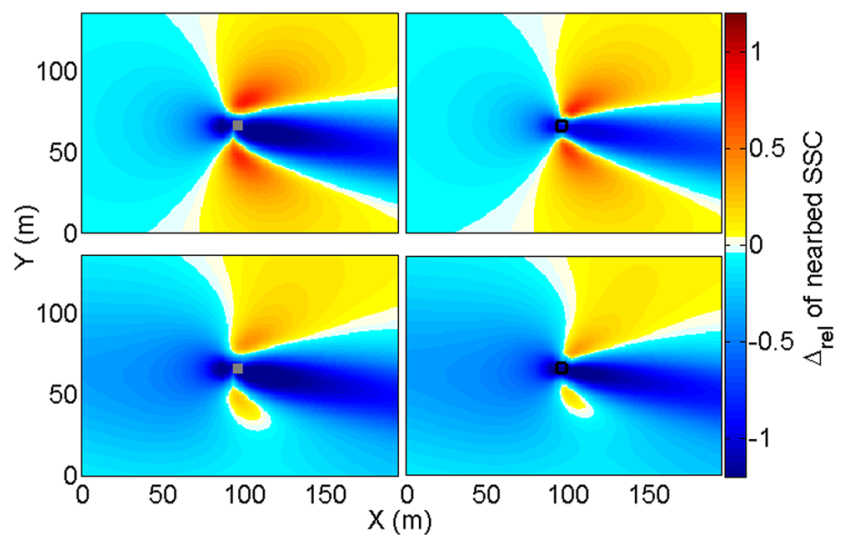

Fig. 16 Relative difference ( $\Delta_{r e l}$ defined in Eq. 12) of suspended sediment concentration (SSC) near-bed around the monopiles located at the bottom left-hand side (top) and at the bottom right-hand side (bottom) in Fig. 13 using explicit approach (left, dry cells are shown in grey) and parameterization approach (right, black lines indicate pile location) at 20:30. The numerical parameters are those of rank 4 presented in Table 2 

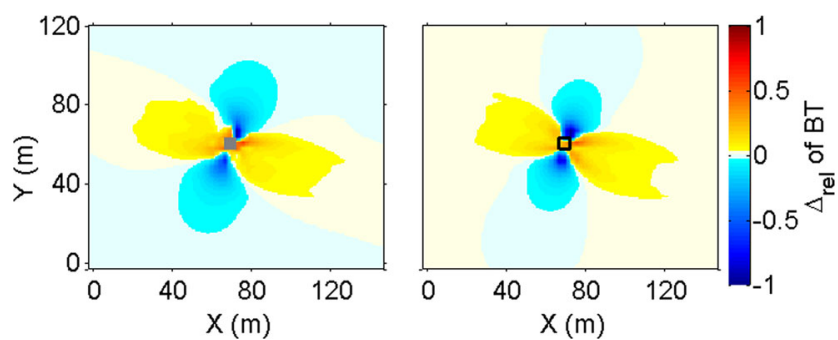

Fig. 17 Relative difference $\left(\Delta_{r e l}\right.$ defined in Eq. 12) of bed thickness (BT) induced by the monopile located at the bottom left-hand side in Fig. 11 in Courseulles-sur-Mer wind farm after $12 \mathrm{~h}$ using explicit approach (left, dry cells are shown in grey) and parameterization approach (right, black lines indicate pile location). The numerical parameters are those of rank 4 presented in Table 2

number on the one hand and to a higher number of cells to represent the monopile on the other hand, leading to a better resolution of flow around the monopile. Results of this case are similar to those with a 6-m-diameter monopile computed with a finer resolution. Using a finer resolution may improve the accuracy of the flow-field near the monopile with more and more physical flow features reproduced. But this was not the aim of the study and regional models are not the best suited for that. Similar differences in the water column are found using various current directions in idealised cases and in the real configuration. This highlights the importance of using a 3D-model when processes close to the bed are studied, in agreement with the observations by Christie et al. (2012). Using nearbed velocities (instead of depth-averaged velocities) to estimate bed shear stresses leads to a more accurate estimation of the bed shear stress.

The quality of the estimated nearbed velocity has direct consequences on bed shear stress estimation. In case 1 (monopile with diameter of $6 \mathrm{~m}$ and represented by four cells), the spatial distribution of bed shear stress is in agreement with Dargahi (1989), Roulund et al. (2005) and Dixen et al. (2012): the bed shear stress is amplified at the sides of the monopile and decreases in front of it. However, the intensity of the effect of the monopile is underestimated by a factor around 5-6. With a larger monopile (case 4, diameter of $15 \mathrm{~m}$ ), the evolution of the bed shear stress upstream of the monopile is particularly well reproduced, the decrease of the bed shear stress due to the monopile is located at a distance of 0.6 diameter as in Dargahi (1989).

Bed shear stress plays a key role in assessing erosion fluxes and more erosion occurs where bed shear stress increases. In the idealised cases with a constant current, the pattern of bed thickness is representative of the first steps of erosion: the bed thickness, initially identical, decreases at the side of the monopile, where bed shear stress is increased. In our model, no erosion occurs in front of the monopile, while Jensen et al. (2006) for instance observed scour all around the monopile. This may be due to the fixed bed around the monopile considered in the hydrodynamical module. This is supported by the work of Dixen et al. (2012) who predicted different distributions of the bed shear stress depending on the shape of the bed around a cylinder. When the bed starts to be eroded, the bed shear stress distribution could change and erosion could occur at new locations. A possible solution to account for seabed morphology modification in our model would be to take into account the variation of the bed thickness in the hydrodynamical module, using a morphological module for instance. However, it is not possible to include this in the present model because scour depth and scour extent are inferior to twice the pile diameter (Whitehouse et al. 2011; Høgedal and Hald 2005). And the only few cells of our grid at this place would not allow an accurate estimate of the scour hole. This phenomena could be parameterized (like for sand ripples) with an increase of bed roughness in cells close to the monopile where scour occurs. With a larger monopile (case 4), the pattern of deposition downstream of the monopile is well reproduced by the model with creation of ripples. This, in contrast, is in agreement with measurements of Jensen et al. (2006). In the real configuration, sediments are resuspended at the side of the monopile, where the bed thickness decreases. And these sediments are deposited alternatively at the left and right-hand side of the monopile due to the change of current direction along the tidal cycle (see Fig. 17). During an entire tidal cycle, the monopile located at the bottom left-hand side in Fig. 11 is reached by the flow wake of the monopile located at the bottom right-hand side during ebb tide. Less sediments are resuspended at the side of the monopile when the wake of a monopile located upstream reaches the studied monopile as the upstream velocity is lower owing to the presence of the wake. This can explain why less sediments are deposited at the left-hand side of Fig. 17 and the asymmetric pattern of the relative difference of the bed thickness in the real configuration.

From Figs. 11 and 13, the wake lengths observed in the real configuration (time $\mathrm{T} 1$ and $\mathrm{T} 3$ ) are in agreement with wake lengths downstream of real offshore wind turbines observed using remote sensing by $\mathrm{Li}$ et al. (2014) (current wake) and by Vanhellemont and Ruddick (2014) (turbid wake). Turbid wakes do not appear downstream of the monopiles in the present computations. Here, the seabed is composed of sand and the settling velocity of sand is too large to create a plume downstream of a monopile. Very fine material could create a plume, as shown in Fig. 8, and as observed in the London Array (Vanhellemont and Ruddick 2014) where fine material is present. However, measurements made by Baeye and Fettweis (2015) in the North Sea around the Belwing offshore wind farm suggest that biofouling of the monopiles and scour protections could also be responsible of turbid wake downstream of a monopile. Organic suspended particulate matter have to be taken into 
consideration to evaluate turbidity resulting from the installation of a wind farm, in order to study the attenuation of light. This has a major impact on primary production by phytoplankton.

This study could be extended to a larger number of monopiles. Modelling shows that a monopile located in this wind farm interacts only with the monopiles located in the same row (see Figs. 11, 12 and 13). From the present computations, the main consequence of this interaction is the modification of the flow at the side of monopile, the wake of the downstream monopile being apparently not modified. It is expected that the pattern of relative difference of velocity magnitude will be similar to the pattern found at the bottom of Fig. 15 around all monopiles located in the wind farm (except the fist line), when current direction and rows are aligned. For other instances, distribution of relative difference of velocity magnitude is expected to be similar to those found in the idealised case. However, further studies on configurations with larger numbers of turbines would be required in order to provide more detailed insights.

Regarding the dry cell or parameterization approaches, each of them present advantages and drawbacks. The dry point approach takes the monopile into account explicitly and it is expected that it is more precise. The accuracy could be easily increased using a higher resolution which would allow to represent the monopile with a larger number of cells. But calculation time will also increase. A simulation was made with a resolution equal to $0.5 \mathrm{~m}$ using a pile with a diameter equal to $6 \mathrm{~m}$. The pattern of computed velocity was similar to the one obtained using a monopile with a pile diameter equal to $15 \mathrm{~m}$ and a resolution equal to $3 \mathrm{~m}$. This confirmed that the number of cells representing the pile is important. However, it is not the purpose of a regional model to use very small cells. The resolution was chosen here to allow, with reasonable CPU times, computations of several monopiles in a configuration of a real wind farm. Moreover, the hydrostatic assumption, for instance, could become erroneous when too small cells are used. A classical CFD software would be more adapted for finer resolution. Another disadvantage of the dry point approach is that it introduces a discontinuity between dry and wet cells in the model, which lead to asymmetry in velocity fields (Fig. 3, left). This problem is not encountered while using parameterization (Fig. 3, right).

The advantage of the parameterization is that it can be adapted even with a coarser resolution in order to represent an entire wind farm with fairly low calculation time. Tests were made in an idealised case to represent a monopile with a diameter equal to $6 \mathrm{~m}$ in a grid having a horizontal resolution equal to $6 \mathrm{~m}$ (not shown here). In that computation, the parameterization technique was also able to reproduce the wake downstream of the monopile. However, the drag coefficient had to be increased to counterbalance the smoothing of the flow due to the coarser resolution. In contrast, it is difficult to impose a drag force on a large number of cells close together, and the parameterization cannot be used with a very fine resolution. In fact, a very small time step would be required for such computations. Parameterization could be improved by a dynamical estimation of the distance between the monopile and the location where the velocity is considered undisturbed (free stream velocity) in the Eqs. 8-11. Here, it is taken $90 \mathrm{~m}$ away from the monopile. This distance is constant whatever the current is. However, in the regional configuration, modifications of the current between this point and the monopile, due to bathymetric changes for instance, are not taken into account. This distance may be modified in regional cases to calculate the drag force with a more appropriate velocity. This has to be analysed further in order to characterize better the free stream, and to adapt the distance to the flow characteristics in order to avoid non-physical perturbations of the flow.

\section{Conclusions}

Two approaches to model the modifications due to offshore wind monopile foundations on hydrodynamics and sediment transport were tested on idealised cases and in a regional configuration. The spatial distribution of velocity, and hence bed shear stress, simulated with the explicit resolution and the parameterization of the monopile, are similar and in agreement with previous research. Vortices are reproduced using a larger monopile which is represented with more cells in the mesh. This leads to the formation of ripples downstream of the monopiles and improves the simulation of the bed thickness evolution. Erosion of the bed and suspended sediment concentration are in agreement with the simulated bed shear stress. The deposits of resuspended sediment downstream of the monopile are well represented because of the use of a sediment transport module which solves advection-diffusion equations. Regional modelling using four monopiles shows that the modifications on the hydrodynamics due to offshore wind monopile foundations can reach the foundation of a wind turbine located downstream, and interactions between monopiles could be observed. In the present study, the relative decrease of velocity due to the upstream monopile wake is equal to $6 \%$ close to the downstream monopile for the flow at medium tide.

Modelling of turbulence could be improved close to the monopile with a good representation of vortex fields. Rogan et al. (2014) performed measurements of turbulence around a monopile in a basin and a formulation of the turbulence around the monopile was established experimentally (Abcha et al. 2015; Rogan et al. 2016). This empirical formulation could be directly introduced in the model to 
parameterize the impact of a cylinder on turbulence (these experiments were however performed for smaller Reynolds numbers, between around $4 \cdot 10^{3}$ and $2 \cdot 10^{4}$, than in our simulations). Moreover, at the present time, advection of turbulent terms in $\mathrm{k}-\epsilon$ equations is not implemented in the model. As a consequence, turbulence source terms added at the location of the monopile in the parameterization scheme are not advected. Adding advective terms could lead to an improvement. Also, during storm events, action of waves is not negligeable. Gunnoo et al. (2014) shows the interaction between wave and current with resonance and modification of Strouhal number. The effect of waves on the hydroenvironmental impacts of the monopile could be considered by the use of the 3D fully-coupled wave-current model MARS-WW3 (Bennis et al. 2011; Bennis et al. 2014) and the effect of the monopile on waves could also be parameterized by adding, for instance, a drag force at the monopile location.

Acknowledgments This paper is a contribution to the European cross-border program Interreg IVA France (Channel) -England OFELIA (Offshore Foundations EnvironmentaL Impact Assessments), cofunded by the ERDF, which involves the universities of Caen, Le Havre and Plymouth. A. Rivier and G. Pinon are supported by the University of Le Havre, A.C. Bennis by the University of Caen and V. Magar and M. Gross by CICESE. A. Rivier acknowledges the support of a post-doctoral grant from the University of Le Havre. The authors are grateful to Frank Dumas (SHOM) and Romain Le Gendre (IFREMER) for providing help for the model configuration of Courseulles-sur-Mer site.

\section{References}

Abcha N, Bennis A, Brossard J, Ezersky A, Garcia-Hermosa I, Gross M, Gunnoo H, Iglesias G, Lebunetel J, Magr V, Miles J, Mouaze D, Perret G, Pinon G, Rivier A, Rogan C, Simmonds D (2015) Report of OFELIA project (European cross-border program Interreg IVA France (Channel) - England) on experimental and numerical modelling

Achenbach E (1968) Distribution of local pressure and skin friction around a circular cylinder in cross-flow up to $\mathrm{Re}=5 \times 10^{6}$. J Fluid Mech 34(04):625-639

Ahmadian R, Falconer RA (2012) Assessment of array shape of tidal stream turbines on hydro-environmental impacts and power output. Renew Energy 44:318-327

Baeye M, Fettweis M (2015) In situ observations of suspended particulate matter plumes at an offshore wind farm, southern north sea. Geo-Mar Lett:1-9

Baptist M, Babovic V, Rodríguez Uthurburu J, Keijzer M, Uittenbogaard R, Mynett A, Verwey A (2007) On inducing equations for vegetation resistance. J Hydraul Res 45(4):435-450

Bennis AC, Ardhuin F, Dumas F (2011) On the coupling of wave and three-dimensional circulation models: Choice of theoretical framework, practical implementation and adiabatic tests. Ocean Model 40(3):260-272

Bennis AC, Dumas F, Ardhuin F, Blanke B (2014) Mixing parameterization: impacts on rip currents and wave set-up. Ocean Eng $84: 213-227$
Bouma T, Van Duren L, Temmerman S, Claverie T, Blanco-Garcia A, Ysebaert T, Herman P (2007) Spatial flow and sedimentation patterns within patches of epibenthic structures: combining field, flume and modelling experiments. Cont Shelf Res 27(8):1020 1045

Camenen B, Larroudé P (2003) Comparison of sediment transport formulae for the coastal environment. Coast Eng 48(2):111132

Christie E, Li M, Moulinec C (2012) Comparison of 2d and 3d large scale morphological modeling of offshore wind farms using hpc. Coast Eng Proc 1(33):sediment-42

Cooper B, Rees J, Coates T (2008) Review of Round 1 sediment process monitoring data-lessons learnt, Final Report, Department of Energy and Climate Change

Dargahi B (1989) The turbulent flow field around a circular cylinder. Exp Fluids 8(1-2):1-12

Defne Z, Haas KA, Fritz HM (2011) Numerical modeling of tidal currents and the effects of power extraction on estuarine hydrodynamics along the georgia coast, usa. Renew Energy 36(12):34613471

Dixen M, Lohmann IP, Christensen ED (2012) Method to predict long time span of scour around offshore wind turbine foundations. Coast Eng Proc 1(33):sediment-88

Edelvang K, Lützen Møller A, Steenberg CM, Zom R, Hansen EA, KM (1999) Horns Rev Wind Power Plant. Environmental impact assessment of hydrography. Report prepared for ELSAMPROJEKT, DHI

Fallon D, Hartnett M, Olbert A, Nash S (2014) The effects of array configuration on the hydro-environmental impacts of tidal turbines. Renew Energy 64:10-25

Frandsen S, Barthelmie R, Pryor S, Rathmann O, Larsen S, Højstrup J, Thøgersen M (2006) Analytical modelling of wind speed deficit in large offshore wind farms. Wind energy 9(1-2):39-53

Ganthy F (2011) Rôle des herbiers de zostères (zostera noltii) sur la dynamique sédimentaire du bassin d'arcachon, in french: 1

García-Hermosa I, Brossard J, Cohen Z, Perret G, Pinon G, Abcha N, Bennis A, Ezersky A, Mouazé D, Rivier A et al (2014) Experimental characterisation of wave induced flow fields due to an offshore wind farm mast. In: First International Conference on Renewable Energies Offshore (RENEW) Lisbon, Portugal

Graf W, Yulistiyanto B (1998) Experiments on flow around a cylinder; the velocity and vorticity fields. J Hydraul Res 36(4):637-654

Gunnoo H, Abcha N, Mouazé D, Ezersky A (2014) Laboratory simulation of resonance amplification of the hydrodynamic fields in the vicinity of wind farm masts. In: Proceedings of the 1st International Conference on Renewable Energies Offshore, Lisbon

Høgedal M, Hald T (2005) Scour assessment and design for scour for monopile foundations for offshore wind turbines. Copenhagen Offshore Wind

Jensen MS, Juul Larsen B, Frigaard P, DeVos L, Christensen ED, Asp Hansen E, Solberg T, Hjertager BH, Bove S (2006) Offshore wind turbines situated in areas with strong currents. Tech. rep., Offshore Center Danmark

Kervella Y (2010) Impact des installations ostréicoles sur 1?hydrodynamique et la dynamique sédimentaire, in french. $\mathrm{PhD}$ thesis, Université de Caen Basse-Normandie

Kirkil G, Constantinescu S, Ettema R (2008) Coherent structures in the flow field around a circular cylinder with scour hole. J Hydraul Eng 134(5):572-587

Lambkin D, Harris J, Cooper W, Coates T (2009) Coastal process modelling for offshore wind farm environmental impact assessment: best practice guide. COWRIE Limited, London

Lazure P, Dumas F (2008) External-internal mode coupling for a 3D hydrodynamical model for applications at regional scale (MARS). Adv Water Resour 31(2):233-250 
Le Hir P, Cann P, Waeles B, Jestin H, Bassoullet P (2008) Erodibility of natural sediments: experiments on sand/mud mixtures from laboratory and field erosion tests. Proc Marine Sci 9:137-153

Le Hir P, Cayocca F, Waeles B (2011) Dynamics of sand and mud mixtures: a multiprocess-based modelling strategy. Cont Shelf Res 31(10):S135-S149

Leballeur L, Latteux B, Girard F (2013) Synthèse de l'étude 2009 Analyse des impacts hydrosédimentaires du projet de parc éolien en mer en Baie de Seine, Rapport MOC N0732 prepared for Eoliennes offshore du Calvados (in french), Actimar

Leendertse J (1970) A Water-quality Simulation Model for Wellmixed Estuaries and Coastal Seas: Priciples of Computation. Rand Corporation, available from the National Technical Information Service. VA, Springfield

de Leon SP, Bettencourt JH, Kjerstad N (2011) Simulation of irregular waves in an offshore wind farm with a spectral wave model. Cont Shelf Res 31(15):1541-1557

Li X, Chi L, Chen X, Ren Y, Lehner S (2014) Sar observation and numerical modeling of tidal current wakes at the east china sea offshore wind farm. J Geophys Res Oceans 119(8):4958-4971

Lindsey W (1938) Drag of cylinders of simple shapes. NACA

Linton C, Evans D (1990) The interaction of waves with arrays of vertical circular cylinders. J Fluid Mech 215:549-569

Ludewig E (2015) On the Effect of Offshore Wind Farms on the Atmosphere and Ocean Dynamics. Springer

Nash S, Olbert A, Hartnett M et al (2014) Modelling the far field hydro-environmental impacts of tidal farms-a focus on tidal regime, inter-tidal zones and flushing. Comput Geosci 71:20-27

Navitus Bay Development Limited Ltd (2014) Environmental statement, Volume B-Offshore, Chapter 5-Physical Processes, Document 6.1.2.5

Neill SP, Litt EJ, Couch SJ, Davies AG (2009) The impact of tidal stream turbines on large-scale sediment dynamics. Renew Energy 34(12):2803-2812

Okubo A (1971) Oceanic diffusion diagrams. In: Deep sea research and oceanographic abstracts, Elsevier, vol 18, pp 789-802

Peaceman DW, Rachford Jr HH (1955) The numerical solution of parabolic and elliptic differential equations. J Soc Ind Appl Math $3(1): 28-41$

Plew DR, Stevens CL (2013) Numerical modelling of the effect of turbines on currents in a tidal channel-tory channel, new zealand. Renew Energy 57:269-282

Ramos V, Carballo R, Álvarez M, Sánchez M, Iglesias G (2013) Assessment of the impacts of tidal stream energy through highresolution numerical modeling. Energy 61:541-554

Rees J, Larcombe P, Vivian C, Judd A (2006) Scroby Sands Offshore Wind Farm - Coastal Processes Monitoring Final Report AEO262 prepared for Marine Environmental Division, Defra and Department of Trade and Industry, CEFAS

Rennau H, Schimmels S, Burchard H (2012) On the effect of structureinduced resistance and mixing on inflows into the Baltic Sea: a numerical model study. Coast Eng 60:53-68

Rivier A, Bennis A, Pinon G, Gross M, Magar V (2014) Regional numerical modelling of offshore monopile wind turbine impacts on hydrodynamics and sediment transport. In: Proceedings of the 1st International Conference on Renewable Energies Offshore, Lisbon
Robins PE, Neill SP, Lewis MJ (2014) Impact of tidal-stream arrays in relation to the natural variability of sedimentary processes. Renew Energy 72:311-321

Roc T, Conley DC, Greaves D (2013) Methodology for tidal turbine representation in ocean circulation model. Renew Energy 51:448 464

Rogan C, Miles J, Simmonds D, Iglesias G (2014) The hydrodynamics of monopile foundations - experimental measurements of near bed and free stream turbulence

Rogan C, Miles J, Simmonds D, Iglesias G (2016) The turbulent wake of a monopile foundation. Renew Energy 93:180 187

Roulund A, Sumer BM, Fredsøe J, Michelsen J (2005) Numerical and experimental investigation of flow and scour around a circular pile. J Fluid Mech 534:351-401

Sánchez M, Carballo R, Ramos V, Iglesias G (2014) Tidal stream energy impact on the transient and residual flow in an estuary: a 3d analysis. Appl Energy 116:167-177

Soulsby R (1997) Dynamics of marine sands: a manual for practical applications. Thomas Telford

Soulsby R, Whitehouse R (1997) Threshold of sediment motion in coastal environments. In: Pacific Coasts and Ports' 97: Proceedings of the 13th Australasian Coastal and Ocean Engineering Conference and the 6th Australasian Port and Harbour Conference; Volume 1, Centre for Advanced Engineering, University of Canterbury, p 145

Sumer BM, Fredsøe J (1997) Hydrodynamics around cylindrical structures. 12, World Scientific

Temmerman S, Bouma T, Govers G, Wang Z, De Vries M, Herman $P$ (2005) Impact of vegetation on flow routing and sedimentation patterns: three-dimensional modeling for a tidal marsh. J Geophys Res Earth Surf 110(F4)

Thiébot J, du Bois PB, Guillou S (2015) Numerical modeling of the effect of tidal stream turbines on the hydrodynamics and the sediment transport-application to the alderney race (raz blanchard), france. Renew Energy 75:356-365

Umlauf L, Burchard H (2003) A generic length-scale equation for geophysical turbulence models. J Mar Res 61(2):235265

Vanhellemont Q, Ruddick K (2014) Turbid wakes associated with offshore wind turbines observed with Landsat 8. Remote Sens Environ 145:105-115

Venayagamoorthy SK, Ku H, Fringer OB, Chiu A, Naylor RL, Koseff JR (2011) Numerical modeling of aquaculture dissolved waste transport in a coastal embayment. Environ Fluid Mech 11(4):329352

Warner JC, Sherwood CR, Arango HG, Signell RP (2005) Performance of four turbulence closure models implemented using a generic length scale method. Ocean Model 8(1):81113

Whitehouse RJ, Harris JM, Sutherland J, Rees J (2011) The nature of scour development and scour protection at offshore windfarm foundations. Mar Pollut Bull 62(1):73-88

Yang Z, Wang T, Copping AE (2013) Modeling tidal stream energy extraction and its effects on transport processes in a tidal channel and bay system using a three-dimensional coastal ocean model. Renew Energy 50:605-613 